\title{
Pengembangan Budidaya Azolla Mycrophilla Sebagai Alternatif Pakan Ternak dan Pemanfaatannya Sebagai Pupuk Bio Organik di Wilayah Masyarakat Desa Baletbaru, Sukowono
}

\author{
Desy Cahya Widianingrum ${ }^{1}$, Nilasari Dewi², Wahyu Indra Duwi Fanata ${ }^{2}$, \\ Ummi Sholikhah ${ }^{2 *}$ \\ ${ }^{1}$ Program Studi Peternakan, Fakultas Pertanian, Universitas Jember \\ ${ }^{2}$ Program Studi Agroteknologi, Fakultas Pertanian, Universitas Jember \\ *Corresponding Email: sholikhah_ummi@yahoo.com
}

\begin{abstract}
ABSTRAK
Desa Balletbaru Kecamatan Sukowono Kabupaten Jember adalah desa yang memiliki potensi besar baik di bidang pertanian maupun peternakan. Pada umumnya masyarakat di desa tersebut masih tergantung pada pemanfaatan pakan ternak hijuan yaitu rumput dan limbah pertanian. Tujuan dari kegiatan pengabdian ini adalah mengenalkan Azolla sebagai alternatif pakan dan bahan pupuk bioorganik kepada masyarakat serta memberikan pelatihan budidaya sehingga terbentuknya suatu kelompok usaha di Desa Balletbaru, Kecamatan Sukowono. Rangkaian kegiatan yang dilakukan meliputi sosialisasi kegiatan, penyuluhan pentingnya Azolla dan manfaatnya sebagai pakan ternak dan pupuk bio-organik, praktek pembuatan kolam dan cara budidaya, monitoring perkembangan Azolla, pemanenan, praktek pembuatan pupuk, serta inisiasi pemasaran Azolla melalui media sosial. Luaran dari program ini diantaranya transfer teknologi tentang Budidaya Azolla sebagai pakan alternatif bernutrisi tinggi dan sebagai pupuk bio-organik, petunjuk/manual yang berisi tentang cara budidaya dan pemanfaatan Azolla sebagai pakan ternak dan pupuk bio-organik, petunjuk/ manual analisis usaha budidaya Azolla, serta hasil produksi ternak yang semakin optimal sehingga menjadi salah satu sumber ekonomi yang dapat meningkatkan penghasilan dan kesejahterahan masyarakat mitra pengabdian dan sekitarnya.
\end{abstract}

Kata kunci: Azolla mycrophilla, desa binaan, kolam budidaya, pakan alternatif, pupuk bio-organik

\section{ABSTRACT}

Balletbaru Village, Sukowono District, Jember Regency is a village that has great potential in both agriculture and animal husbandry. In general, the villagers still depend on the use of forage fodder such as grass and agricultural waste for their cattle feed. Therefore, the purpose of our community service is to introduce azolla plant as the alternative feed and for bio-organic fertilizer material to the villagers and provide cultivation training in order to initiate the azolla business group in Balletbaru Village. The series of activities that have been implemented are as follows; socialization of activities, counseling on the importance and benefits of azolla for animal feed and bio-organic fertilizers, practice for simple ponds construction and azolla cultivation methods, monitoring of azolla growth, harvesting, making of azolla-based fertilizer, and initiating of fresh azolla marketing through social media. The outputs of this program include technology transfer for azolla cultivation as alternative nutritious feed and as bio-organic fertilizer, manuals for azolla cultivation and its utilization for animal feed and bio-organic fertilizer, manuals for business analysis of azolla, and 
JAMALI - Volume. 03, Issue. 01, Maret 2021

increase of livestock production that contribute to the increase of income and welfare of community service partners and the neighbouring area.

Keywords: Azolla mycrophilla, target village, cultivation pond, alternative feed, bio-organic fertilizer

\section{PENDAHULUAN}

Salah satu desa yang mempunyai potensi besar di Kecamatan Sukowono Kabupaten Jember adalah desa Baletbaru. Gambaran umum masyarakat Baletbaru dari sisi perekonomian, masyarakatnya banyak yang bermata pencaharian di bidang pertanian dan peternakan, untuk usaha peternakan yang banyak di kembangkan adalah ternak sapi, ayam dan kambing. Sumber perekonomian yang ada di desa Baletbaru kecamatan Sukowono dari bidang peternakan belum ada upaya pemanfaatan dan pengetahuan terkait budidaya Azola yang bisa di gunakan sebagai pakan ternak alternatif bernutrisi tinggi. Pada umumnya masyarakat di desa tersebut masih tergantung pada pemanfaatan pakan ternak hijaun pada umumnya yaitu rumput maupun hijauan dari limbah panen padi yaitu jerami dan limbah panen jagung yaitu daun jagung. Untuk bidang pertanian tanaman yang dibudidayakan adalah komoditas pangan maupun perkebunan yaitu padi, tembakau. Pemanfaatan pupuk organik masih sangat minim, dan pemanfaatan azola sebagai pupuk bio organik juga belum digunakan. Dari analisis situasi permasalahan di atasmaka melalui kegiatan Program Pengembangan Desa Binaan di harapkan masyarakat dapat belajar dan menambah pengetahuan lebih banyak serta adanya kesempatan, dorongan untuk lebih maju dan kreatif sehingga dapat dipergunakan sebagai sarana peningkatan pendapatan dan kesejahterahan masyarakat di Balletbaru kecamatan Sukowono. Tujuan dari kegiatan ini yaitu

1. Terbentuknya suatu kelompok usaha budidaya Azolla dan pemanfaatannya sebagai pakan ternak bernutrisi tinggi dan pemanfaatannya sebagai pupuk bio organik di desa Balletbaru, kecamatan Sukowono, baik yang di kelola oleh kelompok maupun oleh anggota perseorangan dari masing masing kelompok mitra yang di dampingi oleh akademisi Unversitas Jember.

2. Meningkatkan dan mensinergikan potensi guna menyelesaikan masalah secara interdisilpiner serta memotivasi kelompok mitra untuk lebih maju dan sejahtera.

Azolla microphylla merupakan tumbuhan paku-pakuan yang mengapung di permukaan air. Tanaman ini memiliki daun yang berukuran kecil, tumpang tindih, permukaan daunnya lunak, berwarna hijau cerah, serta memiliki jumlah spora yang cukup banyak. Jenis tanaman Azolla, yang paling umum ditemui dan dimanfaatkan adalah Azolla pinnata dan Azolla microphylla (Alfasane et al., 2019). Kandungan protein tanaman ini cukup tinggi (Handajani, 2000) dengan komposisi asam amino essensial yang lengkap seperti arginin, lisin, dan metionin sehingga potensial digunakan sebagai pakan ternak ungas maupun ruminansia (Thangadurai et al., 2020; Bhatt et al., 2020a, Rahal, 2019). Azolla dapat dimanfaatkan dalam bentuk segar, kering maupun fermentasi. Secara keseluruhan kandungan nutrisi dalam Azolla adalah bahan kering (89.73\%), bahan organik (75.73- 82.66\%), protein kasar (22.48-35.49\%), serat kasar (14.7\%), ekstrak eter (3.7-4.5\%), abu (17.34-24.26\%), Kalsium(1.64$2.58 \%$ ), phospat (0.26-0.34\%), potassium (2.71\%), neutral detergent fibre $(54.85 \%)$, acid detergent fibre (36.57\%), Vitamin B, B12, serta beta karoten (Rahal, 2019; Anithaet al., 2016; Cherryl et al., 2014; Srinivas et al., 2012; Sujatha et al., 2013). Berdasarkan hasil penelitian, campuran azolla ke dalam ransum dapat menekan biaya pakan 18.5 hingga 16.6\% (Murthy et al., 2013). Penggunaan Azolla ini dapat mesubsitusi hijauan dan sumber protein untuk ruminansia (Bhatt et al., 2020), serta 
sumber protein dan mineral untuk babi dan unggas (Wulandari, 2019). Penggunaan Azolla pada sapi perah dapat meningkatkan produksi susu (Rahal, 2019). Manfaat Azolla yang lain diantaranya mampu meningkatkan produksi telur unggas (Rai et al., 2012). Unsur hara lengkap dalam Azolla juga bermanfaat bagi pertumbuhan tanaman (Trada dan Malam, 2020).

\section{Cara budidaya Azolla}

\section{Persiapan kolam}

Siapkan kolam kemudian isi air dengan ketinggian maksimal $30 \mathrm{~cm}$. Habitat asli dari Azolla adalah sawah atau rawa, sehingga media tanam yang paling baik adalah menyerupai dengan habitat asalnya. Pada dasarnya, tanaman ini dapat dibudidayakan dalam kolam tanah, persawahan, atau juga kolam buatan (Bhatt et al., 2020b). Penggunaan pupuk organik, pupuk phospat dan sejenisnya sangat disarankan untuk memberikan nutrisi tambahan bagi Azolla (Rahal, 2019).

\section{Penebaran bibit}

Tahap selanjutnya budidaya azolla adalah penebaran bibit pada kolam ternak, sebelum menebar pastikan kolam tidak berbau dan pupuk telah terfermentasi dengan sempurna. Kolam budidaya akan menghasilkan pertumbuhan lebih maksimal dengan menempatkannya di bawah sinar matahari secara langsung. Untuk menghasilkan Azolla dengan warna hijau segar dapat digunakan paranet sebagai penaung kolam (Effendi dan Pranata, 2019; Rahal, 2019).

4. Pemberian bibit ikan

Bibit ikan dimaksudkan untuk menghambat pertumbuhan jentik nyamuk dalam kolam. Aplikasi ini memberikan dua manfaat sekaligus dalam budidaya Azolla.

5. Pemanenan tanaman paku air atau Azolla microphylla

Pemanenan tanaman paku air ini umumnya dapat dilakukan setelah tanaman berumur sekitar 15 hari setelah pembibitan. Pemanenan tersebut dilakukan saat tanaman paku air tersebut terlihat menumpuk dan menebal dalam kolam (Trada dan Malam, 2020).

\section{METODE}

Berdasarkan permasalahan yang di hadapi oleh mitra Program Pengapdian maka dapat kami uraikan beberapa metode penyelesaian masalah yang di hadapi oleh mitra :

1. Melakukan pembinaan dan edukasi kepada mitra tentang budidaya Azola sebagai salah satu pakan alteratif bernutri tinggi dan sebagai pupuk bio organik.

2. Melakukan pembinaan dan edukasi kepada mitra untuk lebih kreatif dengan alternatif alternatif penggunaan jenis pakan ternak yang bernutrisi tinggi sebagai upaya peningkatan produksi ternaknya dan pemanfaatan Azola sebgai pupuk bio organik yang dapat mengurangi penggunaan pupuk kimia.

3. Melakukan pembinaan dan edukasi kepada mitra untuk lebih faham terkait cara budidaya Azola dan pemanfaatannya sebagai pakan ternak alternatif dan pemanfaatannya sebagai pupuk bio organik. 
4. Melakukan pembinaan dan edukasi kepada mitra untuk lebih kreatif dengan alternatif alternatif penggunaan jenis pakan tenak yang bernutrisi tinggi sebagai upaya peningkatan produksi ternaknya dan penggunaan pupuk bio organik dari azola yang dapat meningkatkan produksi pertniaanya serta mengurangi ketergntungan terhadap pupuk kimia.

5. Melakukan pembinaan dan edukasi kepada mitra untuk pengelolaan dan melihat prospek lebih lanjut dalam pengembangan usaha budidaya Azola sebagai salah satu sumber ekonomi yang dapat meningkatkan penghasilan dan kesejahterahan masyarakat mitra Poengapdian dan sekitarnya.

\section{PELAKSANAAN DAN PEMBAHASAN}

Pengabdian desa binaan ini kami awali dengan sosialisasi di masyarakat (Gambar 1), sosialisi ini bertujuan untuk memberikan informasi awal mengenai maksud, tujuan dan manfaat dari kegiatan pengabdian masyarakat dengan tema budidaya Azolla dan potensi pemanfaatan Azolla sebagai pakan ternak dan sebagai pupuk bio-organik. Kegiatan sosialisasi ini di laksanakan sebelum penyuluhan dan kegiatan lanjutan dari program pengabdian. Hasil dari kegiatan ini adalah respon masyarakat Desa Baletbaru sangat baik dan antusias dalam menerima rencana kegiatan yang kami sampaikan.

Penyuluhan mengenai budidaya dan pemanfaatan Azolla dilakukan di Balai Desa Baletbaru (Gambar 2) dihadiri oleh 25 - 30 orang yang merupakan perwakilan dari masing-masing RT dengan latar belakang masyarakat umum, petani, peternak, dan beberapa orang yang telah memiliki kolam di rumahnya. Rangkaian kegiatan kami yang pertama adalah pengenalan, cara budidaya, serta pemanfaatan Azolla. Pengenalan Azolla yang disampaikan meliputi jenis Azolla yang ada di dunia dan di Indonesia, cara budidaya dan pembuatan kolam portabel berbahan dasar asbes yang kami tampilkan dalam bentuk video, serta pemanfaatan Azolla secara umum.

Materi yang kami sampaikan, selain dipaparkan dalam powerpoint yang ditampilkan pada saat acara seluruh materi juga kami rangkum dalam buku saku yang kami bagikan kepada seluruh peserta untuk mempermudah penyampaian informasi kepada masyarakat. Harapannya, materi ini dapat dibuka kembali oleh masyarakat dan ringkas untuk dibawa kemanapun serta bisa berbagi ilmu dengan masyarakat lain yang belum berkesempatan hadir dan mengikuti kegiatan pengabdian.

Penyuluhan ini mendapatkan reaksi positif dari masyarakat. Berdasarkan diskusi diketahui bahwa sebagian besar petani sudah tidak asing dengan tanaman ini, karena biasa melihatnya di area persawahan akan tetapi, mereka belum mengetahui manfaat dari Azolla dan selama ini menganggapnya sebagai parasite atau gulma yang harus dimusnahkan. Dengan diketahuinya besar manfaat tanaman ini, masyarakat sangat antusias untuk mencoba budidaya Azolla serta mengaplikasikannya

Kegiatan kami selanjutnya adalah pemaparan mengenai manfaat penggunaan Azolla sebagai pakan ternak dan bahan baku pembuatan pupuk bio-organik (Gambar 3). Manfaat Azolla sebagai pakan ternak unggas, ruminansia, serta ikan merupakan pengetahuan baru bagi masyarakat di Desa Baletbaru. Biasanya pakan yang digunakan didesa ini adalah pelet komersial untuk unggas dan ikan serta rumput gajah dan leguminosa untuk ternak ruminansia. Penggunaan Azolla sebagai pakan sangat menarik perhatian masyarakat terutama apabila mereka dapat membudidayakan sendiri tanaman ini. Sehingga biaya pakan dapat diminimalisir. Kualitas Azolla yang tinggi dengan kandungan protein dan asam aminonya yang lengkap menjadi daya tarik peternak untuk mencoba tanaman ini sebagai pakan. 
Praktek pembuatan kolam untuk budidaya Azolla berbahan dasar asbes sebagai dinding kolam yang dikuatkan dengan beberapa bambu sebagai penahan di dinding kolam (Gambar 4). Pada bagian sudut kolam direkatkan dengan semen untuk memastikan masing-masing bagian asbes saling menempel. Rangka kolam ini selanjutnya kami lapisi dengan plastik putih yang ditempelkan dengan lem pada seluruh bagian kolam. Kolam ini berukuran lebar 1,5 $\mathrm{m}$ dan panjang $3 \mathrm{~m}$ dengan tinggi 40 $\mathrm{cm}$. Kolam ini dibuat di 4 lokasi berbeda,

Praktek budidaya Azolla kami awali dengan pengisian kolam kurang lebih 20-30 cm dari atas tanah (Bhatt et al., 2020b). Kolam kemudian diberikan pupuk organik dan SP-36 secukupnya (Rahal, 2019). Kolam yang sudah siap kita semai dengan bibit Azolla sebanyak $1 \mathrm{~kg}$. Budidaya Azolla dilakukan di 4 kolam portabel yang kami buat di lokasi yang berbeda dan pada kolam ikan permanen milik warga. Pada kolam budidaya ini juga kami berikan bibit lele sebanyak 100 ekor/ kolam untuk mengantisipasi adanya jentik nyamuk (Gambar 5).

\section{Monitoring perkembangan budidaya Azolla}

Azolla yang telah disemaikan, setelah 1 minggu telah berkembang biak memenuhi kolam (Gambar 6). Perkembangan tanaman dilihat hingga minggu kedua sebelum pemanenan. Perawatan azolla dilakukan dengan monitoring kuantitas dan kualitas air dalam kolam, perkembangbiakan tunas, serta kemungkinan adanya jentik nyamuk.

\section{Pemanenan Azolla dan praktek pembuatan pupuk bio-organik}

Perkembangan Azolla setelah 2 minggu menunjukkan bahwa tanaman ini telah siap dipanen dengan tanda Azolla telah memenuhi kolam dengan daun yang tebal (Trada dan Malam, 2020). Berdasarkan pengamatan kami, kolam dengan pencahayaan langsung sinar matahari menghasilkan Azolla yang lebih cepat berkembang dan lebih tebal. Azolla ini kemudian kita lakukan pemanenan untuk selanjutnya dicobakan ke ternak dan pembuatan pupuk bio-organik (Gambar 7). Penggunaan Azolla sebagai pupuk cair terbukti berpengaruh pada diameter stem, jumlah daun, berat segar, dan berat kering Lactuca sativa L dimana pemberian POC Azolla microphylla sebanyak $120 \mathrm{ml}^{-1}$ dapat memaksimalkan efisiensi penggunaan urea (Lestari dan Mutryarny, 2020).

\section{Inisiasi pemasaran Azolla}

Inisiasi pengenalan produk Azolla ke masyarakat dilakukan dengan pembuatan media sosial khusus untuk Azolla sukowono. Media yang digemari masyarakat saat ini diantaranya Instagram dan Facebook. Pada media sosial tersebut telah didaftarkan beberapa grup pertanian dan peternakan di Jember. Harga Azolla yang ditawarkan berkisar Rp. 25.000,- sebagai harga awal. Harga ini termasuk murah dibanding harga pasaran Azolla yang berkisar Rp. 30.000 - 35.000,-. Pembeli yang berminat dapat menghubungi langsung Bapak Ibtah, dimana nomor beliau dimasukkan dalam profil pada masing-masing media sosial di atas. Bapak Ibtah merupakan salah satu warga yang dilatih untuk membudidayakan Azolla dirumahnya. Pada praktek dalam memenuhi permintaan pasar, kami himbau kepada Bapak Ibtah untuk dapat mengelola sumber Azolla dari lokasi-lokasi lain didesa Baletbaru yang juga kami latih dalam pengabdian ini.

\section{SIMPULAN}

Azolla sangat mudah dipraktekkan dan dibudidayakan. Manfaat dari Azolla dapat digunakan sebagai pakan alternatif ternak maupun bahan dasar pembuatan pupuk bio-organik. Masyarakat dengan latar belakang petani dan peternak di Desa Baletbaru Kecamatan Sukowono Kabupaten Jember dapat 
JAMALI - Volume. 03, Issue. 01, Maret 2021

menerapkan usaha budidaya Azolla baik untuk mencukupi kebutuhan pakan dan pupuk sendiri maupun untuk diperjual belikan.

\section{UCAPAN TERIMAKSIH}

Ucapan terimakasih di sampaikan kepada Universitas Jember yang telah mendanai kegiatan pengapdian melalui program Hibah Internal tahun 2020

\section{DAFTAR PUSTAKA}

Alfasane, M.A., Bhuiyan, R.A., Jolly, J.A. and Islam, S., 2019. Azolla microphylla Kaulf.(Salviniaceae): A new pteridophytic record for Bangladesh. Bangladesh Journal of Plant Taxonomy, 26(2), pp.325-327.

Anitha, K.C., Rajeshwari, Y.B., Prasanna, S.B. and Shilpa, S. J.Nutritive evaluation of azolla as livestock feed. Journal of Experimental Biology and Agricultural Sciences, 2016, 4,6:670-674.

Bhatt, N., Chandra, R., Kumar, S., Singh, K. and Pratap, N., 2020b. Nutritive Analysis of Azolla pinnata and its Cultivation during Winter Season. Int. J. Curr. Microbiol. App. Sci, 9(3), pp.20122018.

Bhatt, N., Tyagi, N. and Chandra, R., 2020a. Growth Performance and Nutrient Digestibility of Azolla pinnata Feeding in Sahiwal Calves (Bos indicus) by Replacing Protein Content of Concentrate with Azolla pinnataduring Winter Season. Indian Journal of Animal Research, 1, p.6.

Cherryl, D.M.,Prasad, R.M.V., Rao,S.J., Jayalaxmi ,P.and Kumar,D.S. A study on the nutritive value of Azolla pinnata. Livestock Research International , 2014, 2 , 1 : 13-15.

Effendi, I. and Pranata, A., 2019, November. The Effect of Sun Light Intensity on the Growth of Azolla Nicrophylla and its Symbiont Anabeana Azollae in Brackish Water. In Journal of Physics: Conference Series (Vol. 1351, No. 1, p. 012096). IOP Publishing.

Lestari, S.U. and Mutryarny, E., 2020, April. Using POC Azolla Mycrophylla and Urea Fertilizer: Lettuce Plant (Lactuca Sativa L) Context. In IOP Conference Series: Earth and Environmental Science (Vol. 469, No. 1, p. 012115). IOP Publishing.

Murthy, T.N.K., Ashok, M., Thrrumalesh, T., Umesh,B.U. and Natrajan, O.R. Effect of partial supplement of azolla for concentrate supplementation on lactationg cross bred cow.Environment and Ecology,2013,31,2:415-417.

Rahal, A., 2019. AZOLLA-EMERGING ANIMAL FEED. International Research Journal of Natural and Applied Sciences

Rai, R. B.; Dhama, K.; Damodaran, T.; Ali, H.; Rai S.; Singh, B. and Bhatt, P. 2012. Evaluation of Azolla (Azolla pinnata) as a poultry feed and its role in poverty alleviation among landless people in northern plains of India. Vet. Pract., 13 (2): 250-254.

Srinivas, K.D., Prasad, R.M., Raja Kishore, K. and Rao R. E. Effect of Azolla ( Azolla pinnata ) based concentrate mixture on nutrient utilization in buffalo bulls.Indian Journal of Animal Research,2012,46,3 : 268-271

Sujatha, T., Kundu, A., Jeyakumar, S. and Kundu, M.S. Azolla supplementation: Feed cost benefit in duck ration in Andaman Islands. Tamil Nadu Journal of Veterinary Animal Science,2013, 9,2:130-136.

Thangadurai, R., Shanmugam, P.S., Ayyadurai, P. and Balamurali, B., 2020. Success Stories on Large Scale Azolla Cultivation for Semi Intensive Poultry. Biotica Research Today, 2(7), pp.654-655. 
Trada and Malam, K.V., 2020. Azolla (Aquatic Fern) as Bio Fertilizer (Eco-Friendly Agriculture). agrinenv. com, p.29.

Wulandari, E.C., 2019. Kualitas fisik cangkang telur ayam arab dengan ransum kombinasi azolla microphylla dan sumber mineral kalsium berbeda. Wahana Peternakan, 3(1). 


\section{Lampiran}

\section{Sosialisasi kegiatan}
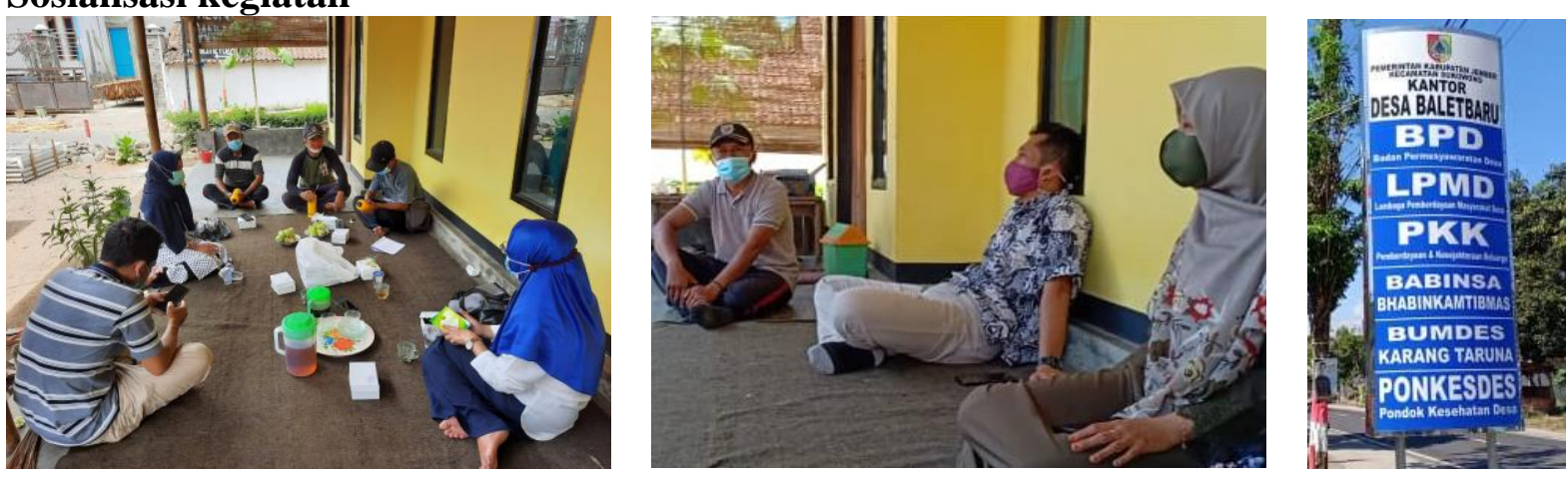

Gambar 1. Sosialisasi Kegiatan

Penyuluhan budidaya dan pemanfaatan Azolla
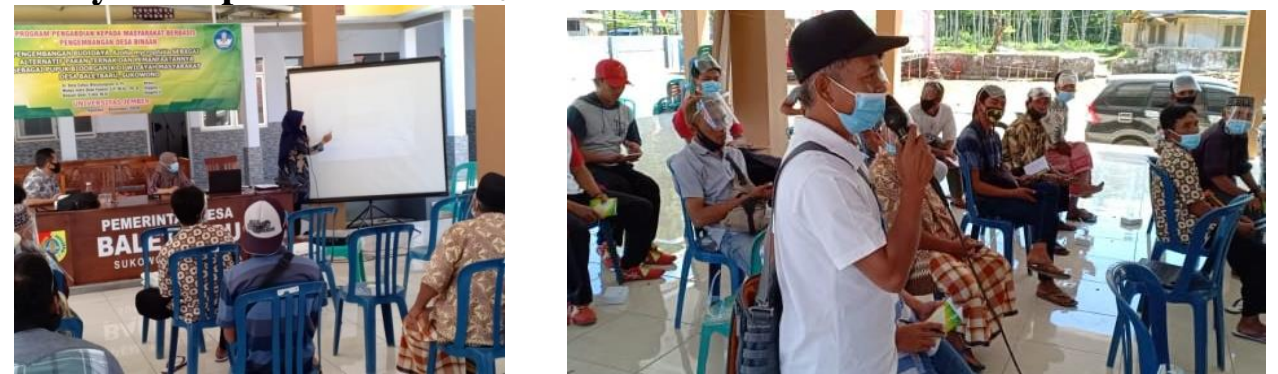

Gambar 2. Kegiatan Penyuluhan Budidaya dan Pemanfaatan Azolla

Penyuluhan penggunaan Azolla sebagai pakan ternak dan pupuk bio-organik

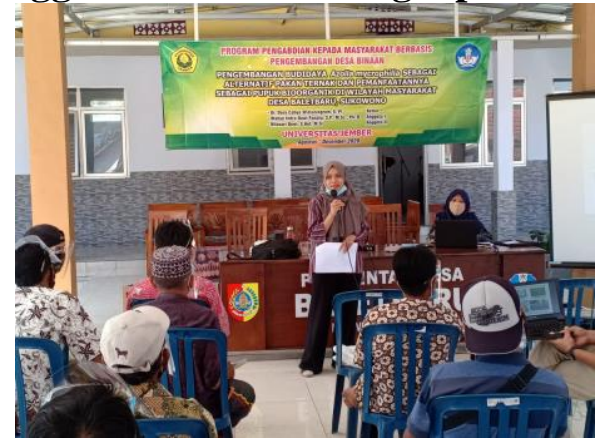

Keunggulan Azolla untuk Pakan Ternak
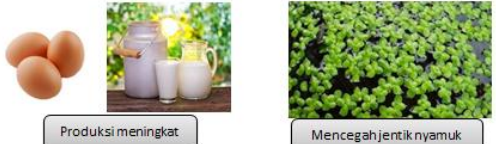

Mencegahjentiknyamuk
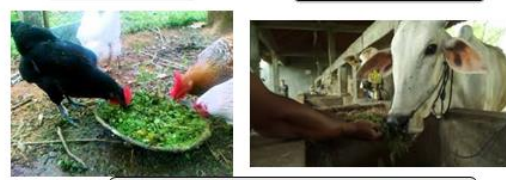

Tekstur lunak, dapat menggantikan pakanuntama

Gambar 3. Penyuluhan Manfaat Azolla sebagai Pakan dan Pupuk Bio-Organik

Praktek pembuatan kolam portabel
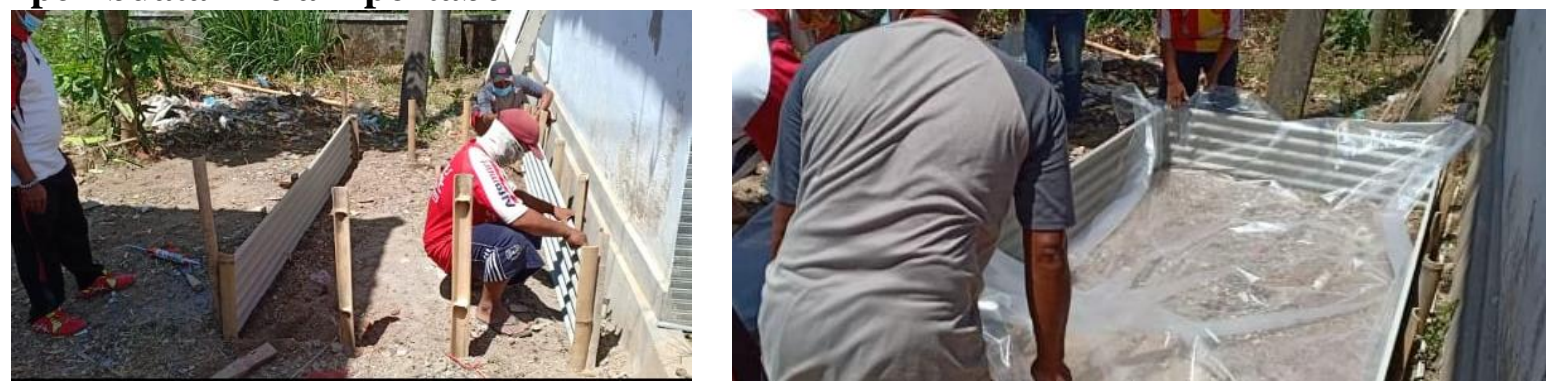

Gambar 4. Kolam untuk Budidaya Azolla

Praktek budidaya Azolla 

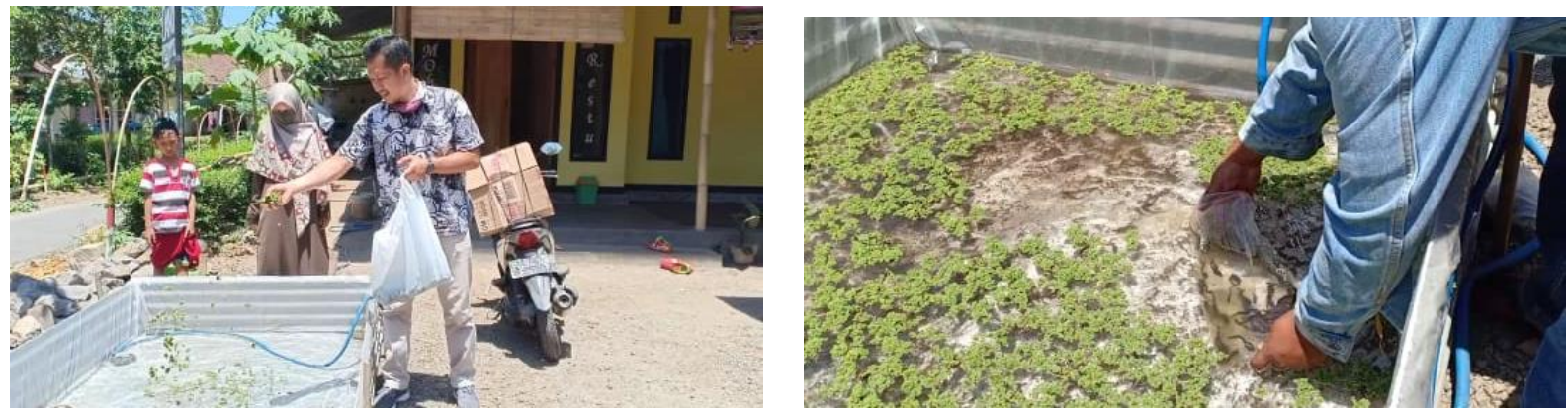

Gambar 5. Praktek Budidaya Azolla

Monitoring Perkembangan Azolla
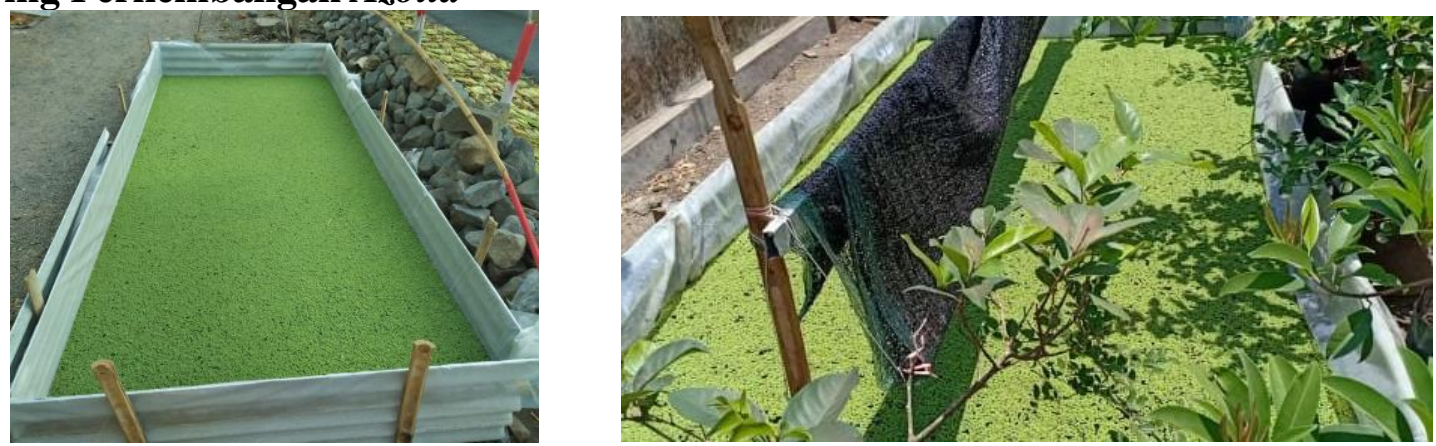

Gambar 6. Budidaya Azolla Umur 1 Minggu

Pemanenan dan Praktek Pembuatan Pupuk Bio-organik
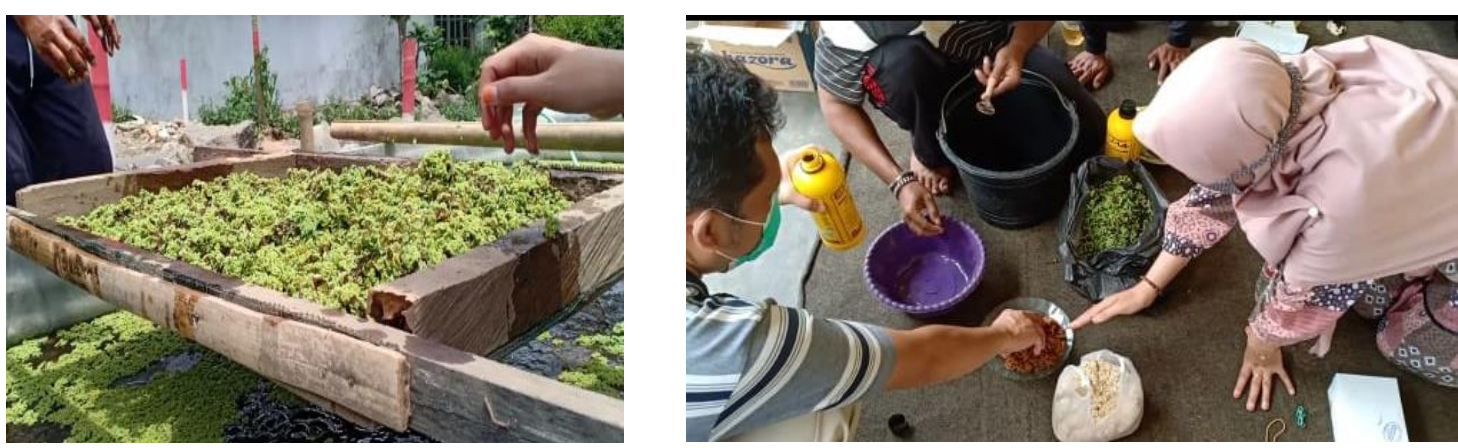

Gambar 7. Pemanenan dan Praktek Pembuatan Pupuk Bio-organik 